emergency, lack of investment for the future, the symptoms of bankruptcy. With the detection of family finances, they can take immediate action to prevent further losses. This will help lead to the achievement of the family's financial goals, namely a prosperous family. The target of community service is the family in the Jatimbar Credit Cooperative community. Jatimbar credit cooperative is a secondary credit cooperative of Second Level Region in West Java Province which is domiciled in Surabaya which serves as the central of regional financial service for Kopdit-kopdit in West Java. There are $25 \mathrm{CU}$, for the dedication of this community is located in Surabaya, 13 pieces.

With the strengthening of family finances through financial Check up activities, this will strengthen the financial welfare of the family, and indirectly also strengthen the cooperative as an institution. All this means the strategy of remembering today Koperasi has become an icon of East Java Province and also Church through its Basic Direction. Based on the above background, herewith submitted a program of community service activities for the members with the title "Financial Check Up Family Finance to strengthen the family welfare of Swadaya Credit Union Members Surabaya".

\section{PROBLEM IDENTIFICATION}

This section identifies the problem and further formulates the problems facing the partnership. To disclose the problem of partners conducted surveys, interviews and discussions with management and management of CU Jatimbar Cooperative (2016). In accordance with the exposure in the background above, the financial portrait as a symptom of financial problems faced by the family is: $90 \%$ of families have not evaluated finances annually, $85 \%$ do not know the percentage increase in net worth each year, and $85 \%$ undocumented family and business purposes, then $75 \%$ they do not know where the money is spent. Based on the management agreement to overcome the above symptoms, and is one of the initial solution is to do financial check-up activities.

While the benefits of community service implementation can be reviewed by three parties. (1) For Institutional Unika Widya Mandala Surabaya, will strengthen the master plan of research that has been formulated that family welfare. Family welfare can be strengthened with skilled family financial checkups that end up getting more prosperous families. (2) For the Proposer, this devotion activity will enrich the field experience in relation to the empowerment of community finances. (3) For the development of this devotional activity is an effort to play a role in achieving the development goals with indicators of welfare achievements of the community.

With the strengthening of family finances through financial Check up activities, this will strengthen the financial welfare of the family, and indirectly also strengthen the cooperative as an institution. All this means the strategy of remembering today Koperasi has become an icon of East Java Province and also Church through its Basic Direction. Based on the above background, herewith submitted a program of community service activities for the members with the title "Financial Check Up Family Finance to strengthen the family welfare of Credit Union Members Jatimbar Surabaya".

\section{METHOD PROPOSED FOR PROBLEM SOLUTION}

The path of problem solving framework can be described as follows: First, identify problem problems faced by the family. The finding of this problem refers to the observation result; Second, starting from the findings of the observation of the subjects of devotion sought solutions and the design of community service materials. Third, translate these solutions into topics and modules with learning objectives.

Here is a troubleshooting framework with Financial Check Up Family Finance To Strengthen Family Welfare Member of Credit Union Cooperative Jatimbar Surabaya

With the strengthening of family finances through financial Check up activities, this will strengthen the financial welfare of the family, and indirectly also strengthen the cooperative as an institution. All this means the strategy of remembering today Koperasi has become an icon of East Java Province and also Church through its Basic Direction. Based on the above background, herewith submitted a program of community service activities for the members with the title "Financial Check Up Family Finance to strengthen the family welfare of Credit Union Members Jatimbar Surabaya". 


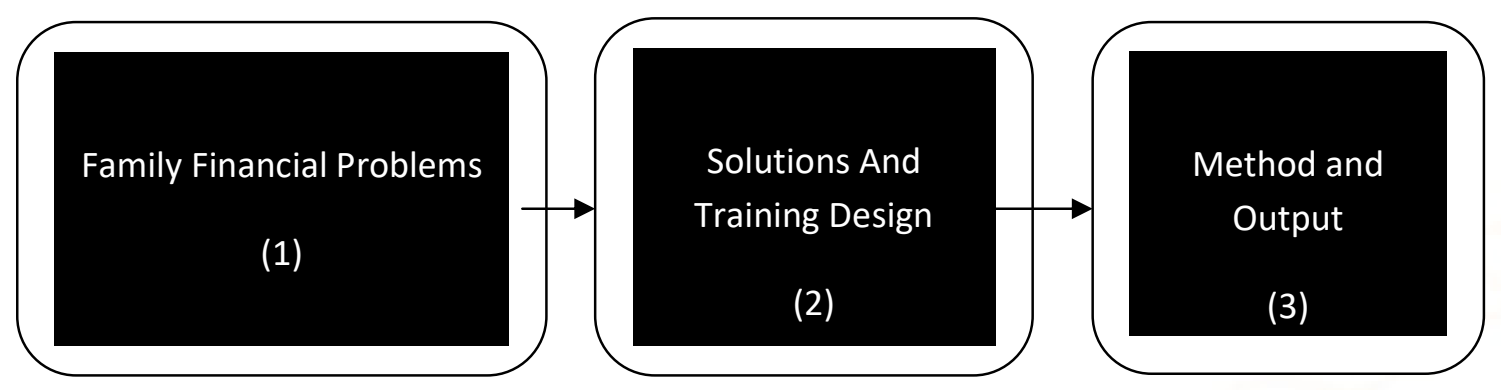

\section{Family Finance Problems}

Being not prosperous means there is only a small income to fulfill all family goals, especially in the event of certain unexpected things such as death, illness, or loss due to natural disasters (Hartono, 2012). In addition to being not prosperous because of financial illness is too wasteful, too much debt, shortage of cash in the emergency, lack of investment for the future, the symptoms of bankruptcy.

Various causes are not prosperous, observations from 20 people provide important information that $90 \%$ of families have not evaluated finances annually, $85 \%$ do not know the percentage increase in net worth each year, and $85 \%$ of family and business goals are undocumented, then $75 \%$ not knowing where the money is spent. Some of these financial portrait indicators are very apprehensive and need to be sought for a common solution so that family goals for building common prosperity can be achieved.

\section{Solutions and Design}

The above problems are obtained from the observation is used to design solutions problem in community service activities. Financial check-up is checking the financial condition of a person or family and can also be business. This activity will greatly help identify the possibility of financial disturbance to the family at an early stage. With so taken action to be done to fix it.

\section{Tool Performs Check up finance}

For that required tools or tools to perform this check-up as well as doctors in checking our health. In general, the examination of financial conditions is done by calculating the ratios or certain comparisons and concluding the results. There are three critical points that must be checked (Cohen and Sebstad, 2006):

1. Situations around the present, measured by liquidity (availability of cash to pay for routine and urgent needs).
2. Impact of past debt decisions, measured by solvency (ability to repay debt obligations at maturity).

3. Future conditions, measured by asset productivity ratios from the results of saving or investing.

\section{Liquidity Check-Up}

In general, all families will require a certain level of liquidity to maintain the ability to pay their regular expenses. Examination of the level of financial liquidity can be done using liquidity ratio, which can be calculated by comparing between liquid assets in the form of cash, savings and deposits with the average needs of one month.

In general, the recommended ratio is between 3 to 6 months (emergency fund). The ratio is too small can complicate the fulfillment of daily needs, especially if there is a risk of short-term impact, such as damaged houses need repair and others.

Conversely, a liquidity ratio that is too large, exceeds the need to cause inefficiencies in managing assets. Cash asset will not give maximum result even decrease inflation. The ratio of liquidity is too great will cover the possibility to gain an investment advantage from assets owned. Thus, it should always be endeavored to maintain liquidity at a certain level in accordance with the financial circumstances and patterns of life.

\section{Debt Check-Up}

Next check-up is related to debt problems. In the language of finance this problem is known as solvency, ie the ability to repay debt at maturity. How to measure it? How to measure it is to calculate the ratio of debt to income payments.

The debt repayment rate can be used to measure the level of ability to repay the debt obligations within a 
period of time, or measure the level of expenditure for debt servicing. How to calculate it is by comparing the total mortgage repayments to be paid within a certain period of time with total earnings in the same time period.

Better decision making for debt is always based on real cash flow, meaning that income is only taken into account when income is actually received. For example, if in this year you plan to sell land assets, income can only be recorded when you have Productivity Asset Check-Up

Spending from everyone's income can be grouped into three main items:

1. To meet daily needs.

2. To pay the debt.

3. To save and invest.

The first two expenditure items we have discussed. Next, let's look at saving and investing post. Paying debts relates to past financial decisions. Daily necessities are the financial problems of today. Saving and investing is a matter for the sake of the future. Without savings and investments, what we are doing will only run until the present, or extreme, we have no time (Nolman, 2012).

As long as income is still able to cover expenses, the immediate impact has not been felt. Most people are like this. When there is a disruption to income, financial life will soon be disrupted, ie, deficit. Without

\begin{tabular}{|c|c|c|}
\hline No & TOPIC & SUB TOPIC \\
\hline 1 & Building a Financial Mindset & $\begin{array}{l}\text { - The significance of Family Financial Planning } \\
\text { - Some financial mismanagement } \\
\text { - Renewing Confidence About Money And } \\
\text { family finance goals }\end{array}$ \\
\hline 2 & Financial Check Up- & $\begin{array}{ll}\text { - } & \text { Financial Check Up Meaning } \\
\text { - } & \text { The tool performs a financial Checkup } \\
\text { - } & \text { Liquidity Check-Up } \\
\text { - } & \text { Check-Up Payable } \\
\text { - } & \text { Productivity of Check-Up Assets } \\
\text { - } & \text { Evaluation and Recommendation }\end{array}$ \\
\hline 3 & Theoretical approach & - Financial Check up Practices \\
\hline 4 & Financial Check Up-Practice Approach & $\begin{array}{ll}\text { - } & \text { Financial planning phase } \\
\text { - } & \text { Challenges and Obstacles to Planning } \\
\text { - } & \text { Solution }\end{array}$ \\
\hline
\end{tabular}

savings and investment, this deficit will not soon be closed, even likely to grow and jeopardize financial stability. Without a surplus of income, it would be very difficult to do financial planning to ensure good financial condition in the future, especially for the long term.

To measure the strength of saving and investment used the ratio of the power of saving. How to calculate is to compare the amount of money saved for investment with income.

Start saving regularly at least $10 \%$ of your monthly net income. There is one more tool or ratio that can help us to see the power of investment in sustaining family finances through the ratio of investment assets to net worth. The ratio of investment strength reflects the level of wealth dependence on investment returns.

This ratio is calculated by comparing income from investment assets with net assets (assets). The bigger this ratio the better. When it comes to 1 or beyond it, you practically do not need to work anymore, because the income from the investment has been sufficient for all your needs. This is the purpose of retirement is coveted by everyone, living well off the investment results that we have.

While topics and sub topics in the Financial Check Up Family Finance activities to improve the welfare of the family of Credit Union Members Surabaya as follows. 
For the current behavior and desired behavior can be arranged as follows:

Current Behaviour

- Do not know the net worth of each member of the cooperative

- Do not know where the money that each member of the cooperative earns is spent.

- Do not know the cash of each member of the cooperative and other liquid assets.

- Not enough personal assets of each koperai member are used as your lifestyle.

- Not much consumptive and productive debt for each member of the cooperative. It's enough as far as debt is borne.

- Have not done family and business - Do not know what percentage increase in net wealth of each member of the cooperative every year.
Desired Behaviour

- Know the net worth of each member of the cooperative

- Knowing where the money that each member of the cooperative earns is spent?

- Know the cash of each member of the cooperative and other liquid assets.

- Knowing the personal assets of each member of the koperai used as a lifestyle

- Not enough consumptive and productive debts for each member of the cooperative? It's enough as far as debt is borne.

- Have not done family and business goals Do not know what percentage increase net assets each member of the cooperative every year.
After identifying the desired behavioral change or financial training check-up objectives, the next step is to determine the specific knowledge, skills and behavior (PFM) desired by the community to be studied with the aim of adapting new behaviors.

\section{Methods Approach Learning}

Target participants of community service activities are the members of the cooperative $\mathrm{CU}$ self-help and prospective members of cooperatives that can be categorized people of god. Thus, the training learning method is adult learning.

The important aspect in adult learning of the participants is not just "passive recepient" or passive receiver, but as an active actor. Or individuals who play an active role in learning. In this case many participants perform activities, they use their brains to examine ideas, solve problems and apply what they learn. Dewasan education is known as student learning approach. To that end, the presentation of community service is seen as an adult education with an active participant approach.

To that end, devotion will be undertaken and create fun and interactive training, using a mix of short and structured learning with interactive practices and activities, combined small discussion groups, providing clear and easy-to-follow materials.
Thus through adult education the speaker is expected to encourage the development of the participants toward three things: to encourage participants, to give the participants the ability to do as others do; and give participants the ability to reject or accept things related to their development. Achieving these three aspects refers to the self-confidence and ability to live independently in accordance with one's status in society.

The measurement of the success of this training will be conducted with discussion between before and after training activities. The results will be dinotulensikan for the needs of further training activities. Some training evaluation questions are: how far is the cooperative member's understanding of the material given in terms of financial check-up? What more value about the given material, and less value about the material given in relation to the financial understanding of the check up? If you want to be given again, which things need to be improved so that financial understanding of this check up participants better.

\section{ACTIONS AND FINDINGS}

Community Service Activity has been conducted under the title "Financial Check Up Family Finance To Strengthen Family Welfare of Members of Credit Union Cooperative Jatimbar Surabaya" on Saturday, September 8, 2017, at 08.30 to 14.45 WIB and September 30, 2017. This activity was conducted at Graha Bumi Pertiwi Blok E no 12. Training 
participants are CU members in Surabaya and Sidoarjo areas. On September 8, 2017 was attended by 28 people and the 30th of Spetember was attended by 27 people

Activity dated September 8, 2017: The training was opened by Julius Koesworo as Chairman of the Community Training Center at 08.30 WIB. The lecture and discussion activities begin at 9:00 am till pk. 12:30 noon (In changer are Mr. Robertus Sigit and Mr. Dominicus Wahyu). After the opening, the event continued with the delivery of the main material of Dreams and Financial Needs. The material begins with explaining how to achieve wellbeing followed by Evaluating Youth Financial Beliefs, In the second session followed by the Second Matter held by Lena Ellitan and a 120-minute discussion. The participants then conducted FGD guided by Lena Ellitan, Ph.D.

Activity dated September 30, 2017: In this activity the discussion was conducted by four groups of participants, each consisting of 7 to 8 participants. Results the discussion is generally described as follows: Firstly, Young people want their future prosperity in which they say welfare is In general terms, prosperity refers to the good, human condition in which people are prosperous, in good health and has the ability. Getting to the reach of services to meet the needs of life with a sense of security. Second, Welfare can be achieved with various kinds such as work according to profession or entrepreneurship.

Associated with financial belief, young people are judged to have confidence related to their finances in the future by studying financial intelligence, improving the ability of business officers by regularly attending various seminars and training in entrepreneurship, menu, entrepreneurial spirit, smart financial management and learning recognize microfinance institutions (Ismawan and Budiantoro, 2005).

In this meeting, CU members also learn about Financial Intelligence. Like what was shared in the media compass some time ago that successful people usually have a good financial intelligence. They are able to manage money so that assets continue to grow, and some even reach financially independent stages. Such circles are no longer need to spend energy and the mind to make money, but the money has been working for "master", that is the already independent. The question is whether members are already financially free.
Produce Productively. Financial intelligence in "best practice" at least covers various aspects. First, how to make money in a productive way. Some employees always think to get a raise constantly. Due to the thought of a continuous increase in salary, work is not concentrated. Or furthermore, the output given to the firm decreases. In turn the performance of the company may decrease which may impact on the inability of the company to pay the salary well.

People, who are financially intelligent, should understand that their source of income is derived from salaries and bonuses, if an employee is concerned. So to be able to get a salary or income more, would not want to give greater output to the company so that company performance also increased.

In other words, in order to get the money equivalent to the time, energy, and thoughts given, do work effectively, which gives effect to the improvement of company performance. That means working with high quality, not just hours of work or high quantity. Protecting money Secondly, how to protect the money already earned. There is the term "easy come, easy go". Earned money with ease, will also end easily. But, worse yet, there are people who have struggled to earn money, but on the other hand is very easy to spend or spend it. Instead, it becomes a "bigger stake, rather than a pole". There are not many formulas to protect money, because the key word is on the behavior of the money owner. If someone is able to control the management of money, then the money is automatically protected. That's the basic principle increased.

Manage your budget. Is it after being able to provide protection against the value of money or money you earn, and then the problem is over? Obviously not yet. Check again whether your financial activities are capable of meeting the third rule that is, managing your financial budget effectively. What does it mean? How much of your income is spent to finance consumptive behavior, for example. Then how much of your income can be saved. Or is your consumptive financing based on planning or simply discharged, following instinct.

In the last session the Team explained that Credit Union: Converts consumptive to productive. The Credit Union Movement is formed to provide some smallscale loans to its members (Robinson, 2001). Joining Credit Union (Credit Union) in the community gives a lot of benefits. Not only to provide ease in obtaining business capital loans but also to finance school and college needs (eg SiPintar savings and educational 
loans) as well as buying household items (eg miscellaneous loans).

The large number of loans made by members makes the Credit Union more developed. However, the ability of members to repay loans is also one of the most important factors in the development of CU. Currently; it is inevitable that many credit cooperatives/other financial institutions have an increasing number of outstanding members (Muljani, Ellitan, Koesworo, 2017). This will result in a "Boom" which will someday destroy the balance / stability of CU development, so members are interested in extending their borrowing limits and there is the possibility of borrowing elsewhere or on loan sharks.

As quoted by the Irish Independent, 'Credit unions must be allowed to fulfill vital role' which in it says that "The most vitally important for the ethos of the credit union movement is it able to continue its work, providing much-needed 'bridging finance 'to families and individuals when they need it ", the most important thing for credit union movement people is that credit unions can run their vision and mission, providing the need for a" financial bridge "for families and individuals when they need some money.

The problem of arrears in the case of member default loans will have an effect on the increase of credit risk which will affect the decision of loan disbursement. It is therefore necessary to take a consciously active member attitude to keep the Credit Union safe, especially for the future and business continuity of credit union members. As we have seen, the lending provided by the $\mathrm{CU}$ also does not see any restrictions, provided that members have the ability to reinstate (Ledgerwood, 2001).

\section{CONCLUSION}

Credit Union is the best choice for the community especially its members to help develop the business and provide the needs and needs of families, individuals and groups. $\mathrm{CU}$ will provide loans as flexible as possible in accordance with the needs of members and society at large. Credit Union helps many young people in turning consumptive behavior into productive as efforts to start a business and so forth.

Education is so important that it becomes the main activity and must be followed by every member, regardless of the level of education and title in its clothing. "The reason for placing the education of financial intelligence as this main activity, because education is a process of action-reflection critically to reality that really happened and proceeds in the life of society (Ismawan, 2000). It is also an effort to manifest human character and experience humane liberation to become an inherent part of any dynamic development of Credit Union.

\section{REFERENCES}

1. Hartono, A., Nasibmu didompetmu, Elex Media, 2012

2. Ismawan, B. 2000. Pemberdayaan Orang Miskin, Refleksi Seorang Pegiat LSM Puspawara, Jakarta.

3. Ismawan, B \& Budiantoro, S. 2005. Keuangan Mikro: Sebuah revolusi Tersembunyi dari bawah., Gema PKM Indonesia,Jakarta.

4. Ledgerwood, J., 2001, Sustainable Banking with the Poor, Microfinance Handbook, An Institutional and Financial Perspective, The World Bank

5. M. Cohen M dan J. Sebstad. 2006. Riset Pasar Untuk Finansial check up, Finansial check up untuk Masyarakat Miskin. Washington D.C,

6. Muljani, N. Ellitan, L. Koesworo, Y. 2017. The Role of Microfinancial Institutions from The Member's Perspective, International Journal of Social Relevance \& Concern, Volume 5 Issue 8 August 2017, pp. 52-60.

7. NoIman, 2012. Salah Kaprah Pengelolaan Keuangan dan Investasi, Elex Media.

8. Robinson,M. S., 2001, The Microfinance Revolution, Sustainable Finance for the Poor, The World Bank 